OPEN ACCESS

International Journal of Management \& Entrepreneurship Research

P-ISSN: 2664-3588, E-ISSN:2664-3596

Volume 2, Issue 7, P.No. 476-491, December, 2020

Fair East Publishers

Journal Homepage: www.fepbl.com/index.php/ijmer

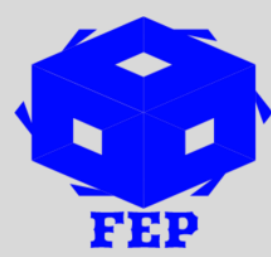

\title{
EFFECT OF ENTREPRENEURIAL MINDSET AND ENTREPRENEURIAL COMPETENCE ON PERFORMANCE OF SMALL AND MEDIUM ENTERPRISE, EVIDENCE FROM LITRATURE REVIEW
}

\author{
Sultan Jemal ${ }^{1}$ \\ ${ }^{1}$ Jimma University College of Agriculture and Veterinary Medicine
}

Corresponding Author: Sultan Jemal

Corresponding Author Email: sultanj100@gmail.com

Article Received: 12-11-20 Accepted: 13-12-20

Published: $30-12-20$

Licensing Details: Author retains the right of this article. The article is distributed under the terms of the Creative Commons Attribution-NonCommercial $4.0 \quad$ License (http://www.creativecommons.org/licences/by-nc/4.0/) which permits non-commercial use, reproduction and distribution of the work without further permission provided the original work is attributed as specified on the Journal open access page.

\section{ABSTRACT}

This study was undertaken to review the literature of the impact of entrepreneurial mindset and entrepreneurial competence on performance of small and medium enterprises (SMEs). The review employed systematic review and was able to identify several components that contribute for enhancing the firms' performance. Most significant entrepreneurial competence components positively and significantly affecting the performance include: opportunity and innovation competence, relational, conceptual, commitment, strategic, organizing, capability of managing resources. Entrepreneurial mindset affects positively and significantly the performance of SMEs and parameters includes: seeking opportunity, creativity, innovation, risk taking, pro-activeness, and alertness to take action. The new development is the established relationship between entrepreneurial mindset and entrepreneurial competence that contribute to business success based on this the review developed conceptual model

The implication includes in order enhancing the performance, entrepreneurs' in SMEs with entrepreneurial mindset, they should acquire knowledge and skill through education and participating in entrepreneurship program offered by government and non-government organization. The government should give priority for people engaged in running the entrepreneurial venture and should strive to offer the entrepreneurial essential skills that enable the individual/people to become an entrepreneur/s as a result helps to enhance their performance of firms.

Keywords: Small and Medium Enterprises; Entrepreneurial Competence; Entrepreneurial Mindset, SMEs Performance, Impact 


\section{INTRODUCTION}

Entrepreneurship is the process by which individuals pursue opportunities regardless of resources they currently control (Brown et al, 2001). This implies entrepreneurship is the practice of establishing one's own business that makes it different from other type of economic activity based on identifying opportunities. Most of the entrepreneurial venture starts being small business aiming to make profit and growth. To pursue and be successful in running entrepreneurial venture the entrepreneur needs to have entrepreneurial mindset and entrepreneurial competence. Entrepreneurial mindset refers to a state of mind which orientates human conduct towards entrepreneurial activities and outcomes. Individuals with entrepreneurial mindsets are often drawn to opportunities, innovation and new value creation also includes assuming associated risk and accepts realities of change and uncertainty (Srinivasa, 2000). Entrepreneurship competencies combine creativity, a sense of self confidence, problem-solving, the ability to marshal resources, ability to identify opportunity, establishing entrepreneurial networks and technological knowledge (Organization for economic cooperation and development, 2018). Entrepreneurial competencies and Entrepreneurial mindset have continuously played a considerable role in the enhancement of businesses (Asenge and Agwa, 2018)

Every opportunity and successful performance of each role and function has a competence requirement which includes knowledge or know-how, the skills, persistence, initiative, efficiency orientation which may affect the performance of small and medium enterprises (Business Studies, 2015). Thus, it is necessary to highlight and summarize the possible experiences and factors focus on entrepreneurial mindset and entrepreneurial competence that contribute for the success of small and medium enterprises (SMEs). the attention was given to SMEs due to the fact that in many nations SMEs considered primary potential source for the economic development and poverty reduction and this is supported by Tehseen and Ramayah (2015) noted that small and medium enterprises (SMEs) have given much emphasis in the recent entrepreneurship researches due to their vital contributions in the economy of every country. SMEs make crucial contributions to job creation and income generation; they account for twothirds of all jobs worldwide (ILO report, 2015 p.1)

This study analyzed the research work done by various scholars on entrepreneurial mindset and entrepreneurial competence its relation with the performance of small and medium enterprises (SMEs) that states a body of literature systematically to analyze the extent of contribution on the performance. In general articles and other sources published over the period of 21 years (2000-2020) considered. Limited studies reviewed the articles related to entrepreneurial mindset and entrepreneurial competence and organizational performance. The review is useful to appraise and understand factors that are critical for enhancing the firms' performance in the context of SMEs. Thus this study aims to review the effect of entrepreneurial mindset and entrepreneurial competence on SMEs performance and suggests direction for further research

\section{METHODOLOGY}

The objective of this study was to review the literature related to the effect of entrepreneurial mindset and entrepreneurial competence on the performance of SMEs. Ultimately provides conceptual model comprises critical factors essential to enhance performance. Systematic review employed and synthesized the evidence under setting of SMEs also appraise 
methodologies used in each article particularly on the establishment of relationship between entrepreneurial mindset and entrepreneurial competence with performance. (University of Melbourne, 2020) suggested that inclusion/exclusion criteria can be using certain setting, study design, date and others. Websites of journals and Google Scholar were utilized as sources to search literatures. Regarding articles majority of the journals publish researches on entrepreneurship and business management subjects considered. In selecting literatures, those relatively recent and no older than 20 years considered that included prior research studies undertaken between 2000 and 2020, however majority of prior studies selected was from 2010 to 2020 and empirical that shows recent development in the topic. The keywords and sub titles were used in searching the literatures: entrepreneurial mindset and performance, entrepreneurial competence and performance, small and medium enterprise, relationship, impact or effect of entrepreneurial mindset/entrepreneurial competence. The search enables to gather a total of 57 documents which comprises 48 journal articles out of this only 7 were review article whereas others 41 were research articles and conducted their investigation using quantitative survey research design relies on descriptive and inferential analysis. In addition, 2 books, 3 thesis paper, $1 \mathrm{PhD}$ dissertation, 1 lecture notes, 2 organization website considered but for interpretation only one dissertation results employed

\section{LITRATURE REVIEW}

\section{SME Definition}

There is no universal definition for SMEs due to countries differ in economic development, types of business engaged whether it is service or manufacturing for instance in related expression as cited by Ofosuaa et al (2015), Egbuogu (2003) noted that definitions of SMEs vary both between countries and between continents. Criteria in the definitions could include various combinations such as: number of employees, financial strength, sales value, relative size, initial capital outlay and types of industry (Iorakpen, 2014). Many countries use size of the employment, the most important criterion. As cited by (Adalessossi and Uktu, 2015), according to United Nations industrial development organization a medium enterprise has 20 to 99 workers in manufacturing firm and exporting companies. However, using number of employments, various countries have varying standards to define small and medium enterprises. As cited by Abawa and Raghurama (2017), Tom and Van der (2008) suggested based on World Bank standards in terms of the number of employment, asset value and amount of sale in terms of money which is indicated in table 1

Table 1

Meaning of SMEs

\begin{tabular}{llll}
\hline Enterprise indicators & Number of employees & Total asset & Total annual sales \\
\hline Medium & $>50 ;<300$ & $>\$ 3,000,000 ;$ & $>\$ 3,000,000 ;<\$ 15,000,000$ \\
Small & $>10 ;$ & $>\$ 100,000 ;<\$ 3,000,000$ & $>\$ 100,000 ;<\$ 3,000,000$ \\
\hline
\end{tabular}

Source: Abawa Esubalew and Raghurama (2017)

Based on the information from the table and summary of conclusion it can be observed that small businesses having from 10 to 300 number of employment qualify to SMEs

\section{Entrepreneur and Entrepreneurship}

An individual or groups of people, who own, operate, and take the risk of a business venture is/are called entrepreneur/s. They are engaged in entrepreneurship, the process of running a business of one's own. Entrepreneurs come from all types of backgrounds and create all kinds 
of businesses (Greene, 2011). This implies that an individual or people who start up, operate, and assume the risk of entrepreneurial venture according to their interest are called entrepreneurs in which they are involved in entrepreneurship which is the practice of running one's own business aiming to make profit. Entrepreneurship is activity in generating ideas and starting business in dynamic environment and making the best opportunities for profit purpose. From these conclusions, entrepreneur is one who identifies the opportunity, pursue and exploit it through making required investment where the major objective is to make profit and growth

\section{Measurements of Entrepreneurial Mindset}

Entrepreneurial mindset is defined as a specific state of mind which orientates human conduct towards entrepreneurial activities and outcomes and correlation analysis proved that in holistic approach, entrepreneurial mindset has significant relationship with performance of SMEs (Asenge et al, 2018). An exploratory study of Neneh, (2012) suggested that acquiring an entrepreneurial mindset requires re-learning how to motivate themselves, take risk, and become creative and innovation. Entrepreneurship education stimulate innovative consciousness of entrepreneurship education, cultivating an entrepreneurial mindset and break through competencies $(\mathrm{Xu}, 2020)$ Enhancing an entrepreneurial mindset and functioning with an entrepreneurial orientation prepares emerging leaders with knowledge, skills and ability to cope with ambiguity and face complexity in organization (Victor, 2018).

Enthusiasm for opportunity positively related to the persistence of business for SMEs and is a key success factor in entrepreneurial activities and process (Suvittawat, 2019). As cited by Jael (2017), McGrath, and MacMillan, (2000) noted that entrepreneurial mindset is about passionately seeking new opportunities, but pursuing only the very best opportunities, focusing on execution and engaging everyone in their domain. By synthesizing these conclusions mindset dimension includes willingness and eagerness in identifying new opportunities and exploit it which provides competitive advantage and help to achieve business success. Having entrepreneurial traits with resourcefulness are crucial to be successful.

Individuals with entrepreneurial mindset are often drawn to opportunities, innovation and new value creation including ability to assume risks and accept the realities of change and uncertainty (Srinivasa, 2000). This expression is also supported by Bosman and Fernhaber (2018) noted entrepreneurial mindset is the inclination to discover, evaluate and exploit opportunities that is involves seeking new opportunities, pursuing opportunities. Extensive literature summarized that an entrepreneurial mindset has close links to innovation and is characterized by persistent pursuit of opportunities, thinking different, intuitive and executive, is risk taking and eliminates status quo (Ekman and Ekman, 2009). According to Kalu and Peace (2017) entrepreneurial mindset is very important for nation's economic development especially if it is viewed through stimulation of the SMEs. The mindset provides ability to develop relevant sustenance for competitiveness as a lifestyle given the dynamic and uncertain business environment. Mulindabigwi and Kayitana (2018) evidenced that mindset variable was positive and significant suggesting that having a grow mindset increases the firm's sustainability. This implies entrepreneurial mindset is one of essential features that entrepreneur need to exhibit helps to achieve growth in business

Literature review developed conceptual model with the entrepreneurial orientation dimensions pro-activeness, innovativeness, competitive aggressiveness, risk taking and autonomy which are essential for survival and enhancing the performance of the business but their effect vary 
(Ashour et al, no date, p.8). Adokiye et al (2017) suggest that innovativeness, pro-activeness and risk taking are essential requirements to stay in business eventually leads to organizational success and found that significant and strong relationship between innovation and performance of SMEs (market share and customer satisfaction), significant but weak relationship between pro-activeness and customer satisfaction as well as market share, significant and strong relationship between risk taking and market share and also customer satisfaction.. From the two conclusions entrepreneurial orientation and entrepreneurial mindset have common dimension in setting of SMEs which considered in this study. Entrepreneurial orientation is a vital force in the economy of any nation because of the strategic role it plays in the achievement of productivity considering dimensions toward risk taking, pro-activeness and the aggressiveness (Odunayo, 2015). Entrepreneurs with entrepreneurial mind help to boost economic growth, create employment opportunity, and introduce goods or services. Anyone can come up with a new idea, have the entrepreneurial mindset is unique feature, entrepreneur must be creative, communicative, and highly inspired to succeed, assume risk but this unique characteristic need to be consistent. Greene (2011) noted that successful entrepreneurs are creative and think of new ways to market and always look for new solutions, act quickly helps to offer better service/ product

The combination of these conclusions leads to understand the applicability of actual opportunities to link entrepreneurial mindset with performance of SMEs.

\section{Measurements of Entrepreneurial Competence}

Entrepreneurial competence is defined as the ability to develop, organize and manage venture along with assuming associated risk that includes key characteristics: social, managerial and networking competences. Entrepreneurial competencies are the set of related skills, attitude and knowledge that help for high achievement and enhance profits which are the main performance elements of SMEs (Muhammad and Aina 2017, p.55). Vignesh and Vetrivel (2017) expressed that competence is considered as an important factor for the excellence in performance, attaining sustainable growth and success in the competitive environment and suggested that it is important to possess high competency for taking business and strategic decisions. Iorakpen I. (2014) suggested that creativity and risk taking are strategies for survival of SMEs and areas of opportunities for business are a solution. Entrepreneurial competence is vital to exist and operate as well as to enhance performance of business in SMEs (Zizile, 2018). It become most important factors to investigate to ensure business successful in constantly changing business environment (Oyeku et al, 2014, p.136).. Competencies are constituted by knowledge, experience, and skills (Xu, 2020). It becomes one of the important factors in order to succeed in modern economy because it affects the development of an entrepreneurial mindset Mohd Ali and Nik Mohd Iskandar, 2016). Asenge and Agwa (2018) noted that entrepreneurs must be equipped with the relevant abilities to carry out various entrepreneurial activities. This implies that has to be one of the qualities of entrepreneurs.

The other components of competence considered that can stimulating the performance of SME is entrepreneurial learning which is abilities to make sense out of their surroundings, experiences and knowledge the other is entrepreneurial social competencies include the effectiveness of the way interact with the people around them (Ameira, 2016). The author argues that the more experience and have relationship with other entrepreneurs as well as having information from the environment enable them to enhance their competence and performance 
of SMEs. Thus information seeking, ability to look for and takes action on opportunities as well as having relationship with others are important to enhance firms performance. As cited by Zizile (2018), Mitchelmore \& Rowley (2013) defined that personal and relationship competencies refer to the ability to negotiate and maintain a good personal network, developing long term trusting and loyal relationship with others. Self-confidence, commitment, leadership, tolerance for ambiguity, creativity, education, and experience along with others are important characteristics for an entrepreneur (Akeem and Adekanmbi, 2016).

Descriptive analysis of Mburu and Gichira (2017) concluded that entrepreneurial factors commitment and innovation had significant and positive influence on the performance of SMEs while independence and experience had a major influence on SMEs performances Zahan and Kanti (2014) finding established significant relationship between entrepreneurial competence of managers and firm performance considering parameters: opportunity recognition, organizing, relationship, strategic, commitment and conceptual competencies. However commitment and conceptual competence were not significant. Based on literature review of Tehseen and Ramayah (2015), Competence area need to include strategic, conceptual, opportunity, learning, personal competence and also external integration the relationship can be enhanced particularly with supplier and customer relationship, thus establishing and maintaining external networking is one of the essential factor for the success of business.

Exploratory study of Robles and Zárraga-Rodríguez (2015) identified competencies that enable the employees to become an entrepreneur that include risk assumption, initiative, responsibility, dynamism, troubleshooting, search and analysis of information, results orientation, change management and quality of work. Onwuchekwa et al (2017) suggested that some of the competencies needed to succeed include: time management, communication, marketing management, decision-making management and financial management competency as a result the business performance can be enhanced. This paper argues the dimension can be categorized into managerial competence

The combination of these conclusions leads to understand the applicability of actual opportunities to link entrepreneurial competence with performance of SMEs

\section{The Effect of Entrepreneurial Mindset on the Performance of SMEs}

A study conducted by Wanguinjeru (2012) revealed that business alertness, innovativeness and creativity respectively played a great role in business performance and concludes that the attributes had positive relationship with performance and significant influence on the performance of SMEs which was measured by market share, sales growth, and number of employees. According to the author alertness is the ability to identify opportunity and innovation is introducing something new in reality whereas creativity is the ability to conceive a new idea. Innovativeness as a dimension of entrepreneurial intensity had strong positive correlation with the performance of SMEs (Kitigin, 2017). Alertness is the competence to identify entrepreneurship opportunities (Xu, 2020). This implies significant application of creativity is important for achieving target. In holistic approach, regression analysis of Mukiri Kimathi et al (2019) revealed that innovation had positive and significant effect on performance of SMEs in which innovation practices includes new products, automating processes, market, unique product, adopting technology.

Ordinary least square regression analysis revealed that mindset (holistic approach) is positive and significant with annual sale that is growth in mindset increases sustainability through 
creativity and assuming risk (Mulindabigwi, and Kayitana, 2018). In the study of entrepreneurial mindset and entrepreneurial competence as determinants of SMEs, using regression analysis Asenge et al (2018) concluded tha,t there is a positive significant effect of entrepreneurial mindset on SMEs performance. The authors' employed holistic approach but discussed parameters innovativeness, creativity, business alertness and risk taking.

Investigation performed by considering common dimensions such as passion, risk acceptance, action orientation, and other behavioral attributes, regression analysis concluded that there is significant relationships between entrepreneurial mindset and aspiration and small business performance and suggest that this help owners to be more market oriented in order for them to survive. Aftan and Hanapi (2018) Empirical study confirmed that there is significant impact of entrepreneur's behaviours considering risk taking propensity and others unlike initiative (proactiveness) on business growth of SMEs context (Ummah, 2019).

Hussain et al (2015) recommended that SMEs should adopt the entrepreneurial orientation mindset in order to attain sustainable competitive advantage and superior performance. Abdul Aziz et al (2014) found that entrepreneurial orientation has a significant positive effect on business performance considering factors such as innovation, risk-taking, and pro-activeness, decision-making, methods and practices. Entrepreneurial orientation is important for success of the business provided that managers/owner exhibit more innovativeness, assuming risk as well as using seeking information to be proactive. Correlation analysis by Ajor and Joy (2020) revealed that a positive significant relationship exist between the risk-taking mindset and organizational sustainability. In another research considering 0.05 significance level using regression analysis in holistic approach, entrepreneurial mindset have positive effect of on the performance of SMEs (Asenge et al,2018).In some items, there is inconsistence of finding considering identical dimensions. For instance in examining influence of entrepreneurial orientation on firms' performance, Ibrahim and Abu (2020) confirmed that pro-activeness, risktaking and autonomy are positive and significantly related to business performance but competitiveness was positive but insignificant. This implies the contribution of competitiveness is less to the performance of SMEs. In contrary quantitative study of Kraus et al (2012) showed that pro-activeness is significantly and positively associated with business performance. As it can be seen from the review in various researches, the measures of entrepreneurial mindset represented by innovation, pro-activeness, risk taking and have relationship with performance of SMEs.

\section{The Effect of Entrepreneurial Competence on Performance of SMEs}

In this section attempt made to discuss literatures focused on what entrepreneurial competence dimensions or indicators relatively contribute to the performance of SMEs.

Regression analysis of Asenge and Agwa (2018) revealed that entrepreneurial competencies significantly affect the performance of SMEs. The authors utilized holistic approach. Mohd Ali, and Nik Mohd Iskandar (2016) established positive and strong relationship between entrepreneurial competence (innovation capability and quality management) and organization performance, but entrepreneur competence did not contribute to the performance of SMEs where competence component were relational as well as business and management. But author consider very small size

Vijay and Ajay, (2011) suggested that engaging in entrepreneurial role of SME entrepreneurs require strategic, opportunity, commitment, conceptual competencies and authors revealed that 
these competencies are positively related to business success in SME. Entrepreneurial competence (opportunity, relationship, analytical, innovative, operational, human, strategic, commitment, learning and personal strength competencies) and organizational capability have positive and significant relationship (Sanchez, 2012). For the better performance of SME, entrepreneurial competencies and dynamic capabilities are perceived as the prospective solutions (Hashim et al, 2018). Regression result showed that opportunity competence is statistically significant to profitability whereas conceptual, strategic and commitment significant effect on organizational effectiveness in the context of agro based SMEs (Ayodotun S., 2017). Abaho et al (2017) found existence of relatively high correlation between entrepreneurial competencies measures of relationship building compared to commitment with SME performance. Regression analysis of Kabir et al (2017) established relationship between competence and performance of SMEs specifically strategy, opportunity and organizing competencies have positive direct relationship with firm performance. Using confirmatory factor analysis, personal entrepreneurial competence exhibited by the SMEs owners is determining factors for performance in which planning, persistence, and commitment are perceived significant predictors of small firm performance (Baylie and Singh, 2019).

Regression analysis of Gerli et al (2012) concluded that relational dimension primarily affects organizational results such as efficiency orientation; organizational awareness and teamwork are related to a higher firm financial performance. As cited by Mohammed et al (2017), Kaur and Bains (2013) indicated that strategic, opportunity and organizing competencies significantly affect the firm performance. Investigation of entrepreneurial competence on performance of SMEs, correlation analysis and regression analysis revealed that entrepreneurial capability and growth strategy has an influence on SMEs success (Nasir and Chellakan, 2020)

\section{Link between Entrepreneurial Mindset and Entrepreneurial Competence}

Competencies are described as the essential characteristics in developing entrepreneurial mindset there is a positive significant relationship between entrepreneurial mindset and selfentrepreneurial competencies (Lope and Arivayagan, 2016). Entrepreneur competencies become one of the important factors in order to succeed in modern economy because it affects the development of an entrepreneurial mindset Mohd Ali and Nik Mohd Iskandar, 2016). Asenge and Agwa (2018) in the study of entrepreneurial competencies and entrepreneurial mindset as determinants of small and medium scale enterprises performance suggested that combined model is a strong predictor of performance that represents both themes entrepreneurial mindset and entrepreneurial competence. Common dimensions or attributes of entrepreneurial mindset and entrepreneurial competence that contribute for enhancing performance considered in the literature illustrated in table 2. Performance measurement is through a subjective approach can be employed (Abdul, A. et al, 2014). For instance customer satisfaction and market share (Adokiye and Onuoha). Another dimension can be annual sale (Mulindabigwi Ruhara and Kayitana, 2018)

Table 2

Common Factors Examined Entrepreneurial Mindset and Entrepreneurial Competence

\begin{tabular}{ll}
\hline Entrepreneurial mindset & entrepreneurial competence \\
\hline Innovativeness the introduction of new things, & $\begin{array}{l}\text { Opportunity competence ability of identifying } \\
\text { opportunity, innovation competence }\end{array}$ \\
ideas, or ways of doing & \\
\hline
\end{tabular}




\section{Opportunity recognition is state of identifying}

superior opportunity

Pro-activeness plan to achieve required performance, confidently identifying opportunities and initiation of new items, service/ market, attitude to make change

Quick action/alertness promptly identifying value, gathering information and identifying value of an item or service

Creativity is generation of novel, useful idea, practicing innovation and means to display entrepreneurial behaviors
Relational competence: human relations competence, external relationship, ability to negotiate, long term trust and loyal relationship

Conceptual related to analyzing and decision making, problem solving, thinking intuitive

Commitment dedicated and determined behavior, capability drive to move ahead with the business, being initiative

Strategic capability related to setting, evaluating and implementing the strategies of the firm

Organizing organization of internal and external human, physical, financial and technological resources,

Managing resources : Capability of effectively management of resources

\section{Source (own from the literature review)}

Synthesizing all conclusions, entrepreneurial mindset and entrepreneurial competence have relationship and together influence the performance. However limited research undertaken in considering combined set effect of mindset and competence on performance of SMEs, further research required. Thus based on this established relationship and individual examination on these themes, this paper presents conceptual frameworks considering both themes as factors related to each other which are essential to ensure business success comprises critical parameters indicated in figure 1. Based on the model, the extent of relative contribution to the performance can be determined so that enables the entrepreneurs can have insights in which mind parameter and competence area more emphasis given to enhance success of the business and further finding will provide additional insights to improve of the performance of SME.

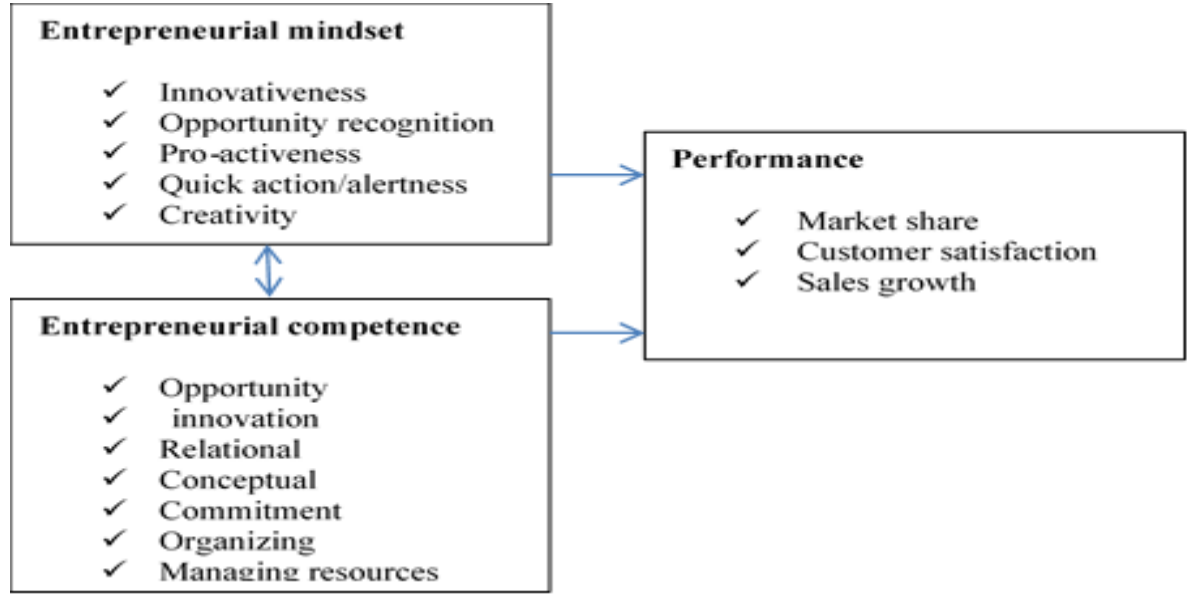

Figure 1 Conceptual model

Source: own based on literature

\section{DISCUSSION}

This review evidenced that entrepreneurial mindset and entrepreneurial competence have positive and significant effect on the performance of SMEs in addition both themes helps firms' to survive and compete in better way. (Lope P. and Arivayagan, 2016; Asenge and Agwa, 2018) 
established relationship between entrepreneurial mindset and entrepreneurial competence. Based on these conclusions, improving clustering entrepreneurial mindset and competence factors enhance performance of SMEs and helps to stay in business. Limited authors consider these combined components/both themes in their study. Thus this discussion is reported by merging the findings of prior studies

There is positive significant relationship between entrepreneurship mindset with some measures of business success which implies as innovativeness, prompt action, creativity, pro-activeness and risk taking of component level improves, the performance of SMEs also increases (Wanguinjeru, 2012; Kraus et al, 2012; Abdul Aziz, 2014; Adokiye and Onuoha, 2017; Asenge et al, 2018; Mulindabigwi Ruhara and Kayitana, 2018; Ummah, 2019; Ajor and Joy, 2020) similarly innovation had positive and significant effect on performance of SMEs (Aftan and Hanapi, 2018; Mukiri Kimathi et al, 2019). This implies as entrepreneur mindset more orientated toward innovativeness, risk taking propensity, pro-activeness and alertness enhances performance. In contrary initiative (pro-activeness) had insignificant contribution on business growth of SMEs (Adokiye and Onuoha, 2017; Ummah, 2019). This implies that plan and initiation to start own business and confidence contribution in improving competence ultimately on the growth of SMEs is relatively low. Inconsistence finding noticed from prior research but somewhat disagree with the finding of Mulindabigwi and Kayitana, (2018) revealed that the combined mindset variable was positive and significant suggesting that having a grow mindset increases the firm's sustainability. Moreover, Aftan and Hanapi (2018) confirmed that there are significant relationships exist between entrepreneurial mindset and aspiration and small business performance.

Related to competence, Asenge and Agwa (2018) revealed that entrepreneurial competencies significantly affect the performance of SMEs. Competence such as recognizing opportunity, organizing, relationship, strategic commitment, independence, experience, have significant relationship to the performance of SMEs (Sanchez, 2012; Zahan. and Kanti, 2014; Mburu and Gichira, 2017; Mohammed et al. 2017; Baylie and Singh, 2019) and in some variable measurement partly agrees with (Vijay and Ajay, 2011; Gerli et al ,2012; Mohd Ali and Nik Mohd Iskandar,2016; Ayodotun, 2017; Kabir et al ,2017). In contrary Mohd Ali and Nik Mohd Iskandar (2016) indicated that relationship competence did not contribute to enhance the performance of SMEs. However, in majority of study confirmed that improving the ability to identify opportunity, organizing, innovation competence determination and dedication of an entrepreneur in the operation results increase of the performance of the business. In contrary Zahan and Kanti (2014) suggested that commitment and a conceptual competency were not significant for firm's performance whereas Vijay and Ajay (2011) showed that both competencies were positively related to the performance of the firm and concluded that it is one of the managerial role of entrepreneur required to be successful in business. In contrary high correlation between entrepreneurial competencies measures of relationship building compared to commitment with SME performance (Abaho et al, 2017). In this review inconsistence finding observed on the dimension of relational and commitment competence and also limited investigation on other entrepreneurial competence dimension that require further investigation based on suggested conceptual framework. That is the literature discussed a various listing of entrepreneurial mindset but some factors were omitted that is not investigated or sufficiently 
examined for instance creativity, new value creation (Srinivasa, 2000). In case of entrepreneurial competence some factors not yet measured or sufficiently tested such as managerial competence Onwuchekwa et al (2017). Akeem and Adekanmbi (2016) also suggested that possession of self- confidence, tolerance for ambiguity and education which are vital to be successful in running entrepreneurial venture that could increase the chances of success in SMEs as well as enable to compete in dynamic environment

Finally new development in this review indicated that entrepreneurial competence and entrepreneurial mindset have relationship. Entrepreneurial competencies become one of the important factors in order to succeed in running entrepreneurial venture can be acquired through knowledge and experience which affects the development of an entrepreneurial mindset

\section{CONCLUSION}

The results provided substantial list of entrepreneurial mindset and entrepreneurial competence factors for that by improving helps to achieve the performance of SMEs

Majority of the researchers considered entrepreneurial mindset dimensions focused on seeking opportunity, risk taking, innovation, alertness in action and pro-activeness to investigate their impact on the subjective performance of SMEs market share, sales growth, number of employee and customer satisfaction. Entrepreneurial mindset has positive and significant impact on performance of SMEs which indicates the higher these attributes of mind set leads increase the performance of the business in the context of SMEs

There is evidence that showed there is a positive relationship between entrepreneurship mindset and entrepreneurial competence, some measures of business success which indicates when entrepreneur mindset demonstrate entrepreneurial orientation with competence, performance of SMEs increases

Based on this review it can be conclude that the higher of the entrepreneurship competence possessed by the entrepreneurs the greater it is for their business to succeed in SMEs. Competence component includes opportunity, innovation commitment, conceptual, capability to effectively manage the use of resources, relationship competence, strategic, significantly affect the performance. Enhancing these competency helps to increase SMEs performance.

Finally, it can be concluded that having the required entrepreneurial competence were important for the business success which affect entrepreneurial mindset as a result influence the performance of firm. Therefore, the appropriate competence is unavoidable and guarantees to enhance the performance of SMEs

\section{IMPLICATION}

Based on this review of the finding of the conclusion, the implications forwarded that to increase performance of firms in setting of SMES. SMEs with entrepreneurial mindset in order to enhance their performance they should acquire knowledge and skill through education and participating in entrepreneurship program offered by government and non-government organization. Entrepreneurs in SMEs with entrepreneurial mindset want to enhance their performance they should take into account of all entrepreneurial competence: strategic, ability to identify opportunity and effectively marshal resources, relationship/networking with others. The government should give priority for people engaged in running the entrepreneurial venture and should strive to offer the entrepreneurial essential skills that enable the individual/people to become an entrepreneur/s subsequently this leads to enhance the performance of business 


\section{Further Research}

The majority of the data obtained from the studies employed descriptive and quantitative survey study but they had little open-ended question type which provides little understanding for a qualitative aspect, additional descriptive information was not included. Qualitative approach can be employed using interview; case studies on practice of SMEs would provide additional data that benefit to extend knowledge to literature. For example, exploring specific reasons behind the alertness in action, strategic, experience, commitment, conceptual could lead to enhance the firm's performance. Thus, we can explore what factors may still omitted more influential to the success of business in setting of SMEs

The relative importance of entrepreneurial mindset and entrepreneurial competence can be investigated to understand the extent of each variables contribution important to determine the most predictor of success of the business.

\section{References}

Abaho, E., Sylvia, A., Ntayi, J., \& Kisubi, M. (2017). Firm Capabilities, Entrepreneurial Competence, and Performance of Ugandas SMEs. Business Management Review, 105125. Retrieved from https://www.researchgate.net

Abawa, E.A., \& Raghurama, (2017). Micro, Small and Medium Enterprises (MSMEs) Development Strategies in Ethiopia: Retrospective and Prospective Analysis. International Journal of Commerce, Business and Management, 6(1), 11-20. Retrieved from http://www.iracst.org/

Abdul, A.R., Tajudin, A., Mahmood, R., \& Abdullah, M. (2014). The Relationship between Entrepreneurial Orientation and Business Performance of SMEs in Malaysia. International Journal of Management Excellence, 2(3), 221

Adalessossi, K., \& Uktu, B. (2015). Financing Difficulties of Small and Medium Enterprises (SMEs) in the West African Economic and Monetary Union (WAEMU) Area. ChinaUSA Business Review, 14(2), 79-99. https://www.researchgate.net/publication

Adokiye, J., \& Onuoha, B. C. (2017). Entrepreneurial mindset and organization success in SMEs I Rivers state. International Journal of Advanced Research and Publications, 1(5), Retrieved from https//www.ijarp.org

Aftan, Y., \& Hanapi, M. (2018). Entrepreneurial mindset and aspiration as critical success factor for small business performance in Iraq. Asian Journal of Multidisciplinary, 6(3) Retrieved from https://www.semanticscholar.org

Ajor, L., \& Joy, C. N. (2020). Risk-Taking Mindset and Organizational Sustainability of Small and Medium Enterprises in Bayelsa State. Nigeria Global Scientific Journal 6(1). Retrieved from www.globalscientificjournal.com

Akeem, O, A., \& Adekanmbi, O. (2016). Relationship between Entrepreneurial Characteristics and Performance of Small and Medium Scale Enterprise (A Study of SMEs in Yaba LCDA). International Journal of Business and Social Science, 7(9) Available at https://ijbssnet.com/

Ameira, M. Y. A. (2016). Stimulating Malaysian SMEs performance: the synergistic role of entrepreneurial capital, entrepreneurial competencies and institutional support $(\mathrm{PhD}$ Dissertation), Available at http://eprints.usm.my 
Asenge, E., Diaka, H., \& Soom, A. (2018). Entrepreneurial Mindset and Performance of Small and Medium Scale Enterprises in Makurdi Metropolis, Benue State-Nigeria International Journal of Innovation, 6(2), 124-146. Available at: http://dx.doi.org

Asenge, E., \& Agwa, T. (2018). Entrepreneurial Competencies and Entrepreneurial Mindset as Determinants of Small and Medium Scale Enterprises Performance in Nigeria Global Journal of Management and Research 18(13) https://webcache.googleusercontent.com Ashour, H., Abbas, A., \& Allam, S., (no date.) The Effect Of Entrepreneurial Orientation On Business Performance: Evidence From Small Medium Size Enterprise. Risk Governance and Control: Financial Markets \& Institutions. Available at: https://webcache.googleusercontent.com

Ayodotun, S.I., Maxwell, A. O., Adunola Oluremi, O., \& Ifeoma, C. N. (2017). Enhancing The Performance Of Agro-Based SMES: The Role Of Entrepreneurship Competencies. Covenant Journal of Entrepreneurship 1(1) Available at: http://eprints.covenantuniversity.edu.ng

Baylie, A., \& Singh, M. (2019). Entrepreneurial Competencies and Success of Small and Medium Enterprises (SMEs): Evidence from Ethiopia. European Journal of Business and Management, 11(19), 14-31. Available at: https://www.iiste.org

Bosman, L., \& Fernhaber, S. (2018). Teaching the Entrepreneurial Mindset to Engineers Springer Preview. Doi:10.1007/978-3-319-61412-0

Brown, T., Davidsson, P., \& Wiklund, J. (2001). An operationalization of Stevenson's conceptualization of entrepreneurship as opportunity-based firm behavior. Strategic Management Journal, 22(10), 953-968. Available at: https://eprints.qut.edu.au

Business Study. (2015). Entrepreneurship development retrieved from https://ncert.nic.in/ncerts

Ekman, S., \& Ekman, A. (2009). Designing an Entrepreneurial Mindset In Engineering And Management. International Conference on Engineering Design. The Design Society a worldwide community. Available at: https://www.designsociety.org/publication/28848/

Greene, C. (2011). Entrepreneurship 21st century business 2nd edition South-Western, Cengage Learning. Retrieved from http://www.mim.ac.mw/books

Gerli, F., Tognazzo, A., \& Gubitta, P. (2012). what makes Italian SME entrepreneurs successful? The leverage effect of relational competencies. Rivista Piccola Impresa/Small Business, 3

Hashim, N. A., Raza, S., \& Sobri, Minai, M. (2018). Relationship between Entrepreneurial Competencies and Small Firm Performance: Are dynamic Capabilities the missing link? Academy of Strategic Management Journal, 17(2), 1-10.

Hussain, J., Ismail, K., \& Akhtar, C. (2015). Linking Entrepreneurial Orientation with Organizational Performance of Small and Medium Sized Enterprises: A Conceptual Approach. Asian Social Science, 11(7), Available at: http://www.ccsenet.org

Ibrahim, \& Abu. (2020). Influence of Entrepreneurial Orientation on Firms Performance: Evidence from Small and Medium Enterprises in Nigeria. International Journal of $\begin{array}{llll}\text { Economics and } \quad \text { Financial } & \text { ISsues, }\end{array}$ https://www.researchgate.net/publication 
ILO report (2015). Small and medium enterprises and decent and productive employment creation International Labor Conference, 104th Session Printed by the International Labour Office, Geneva, Switzerland

Iorakpen, I. J. (2014). Evaluation of survival Strategies of Small and Medium Enterprise in Benue State, Nigeria. International Journal of Academic Research in Accounting, Finance and Management Science, 4(2). Retrieved from http:// www.hrmars.com

Jael, A., O. (2017). Relationship between entrepreneurial mindset and performance of small and medium enterprise in Kisumu county, Kenya. International Journal of Business Quantitative Economics and Applied Management Research, 3(11). Available at http://ijbemr.com/wp-content

Kabir, M., Izwar, I.H., \& Mohammad, K. (2017). Entrepreneurial Competence Determinants For Success of Female Entrepreneurs in Nigeria. Indonesian Journal of Business and Entrepreneurship, 3(2) Available online at http://journal.ipb.ac.id/index.php/ijbe or DOI:10.17358/IJBE.3.2.143

Kalu, A., \& Peace, N. (2017). Assessment of Entrepreneurial Mindset on Sustainability of Nigerian Smes. International Journal of Business and Entrepreneurship Research, 11(2) 1-16 Available at: https://www.semanticscholar.org

Kitigin, B. (2017). The Influence of Innovation on The Performance of Small and Medium Enterprises in Eldoret Town, Kenya. International Journal of Small Business and Entrepreneurship Research, 5(4), 35-44. Retrieved from www.eajournals.org

Kraus, S., Coen, R.J., Hughes, M., \& Hosman, V. (2012) Entrepreneurial orientation and the business performance of SMEs: a quantitative study from the Netherlands. Review of Management Science. Retrieved from at Springerlink.com

Lope Pihie, Z.A., \& Arivayagan, K. (2016). Predictors of Entrepreneurial Mindset among University Students International Journal of Humanities Social Sciences and Education (IJHSSE) 3(7). http://dx.doi.org

Mburu T. B., \& Gichira, R. (2017). Entrepreneurial Factors Influencing Performance of Small and Medium Enterprises in Ongata Rongai Town,Kajiado County,Kenya The Strategic Journal of Business \& Change Management, 4(3), 347-364. Retrieved from www.strategicjournals.com

Mohammed, K., Ibrahim, H., \& Shah, K. (2017). Empirical Evidence of Entrepreneurial Competencies and Firm Performance: a Study of Women Entrepreneurs of Nigeria International Journal of Entrepreneurial Knowledge, 5(1). Available at: https://www.researchgate.net

Mohd, Ali, K. A., \& Nik, Mohd, Iskandar, N.I. (2016). The effect of business innovation capability, entrepreneurial competency and quality management towards the performance of Malaysian SME's International Journal of Business, Economics and Law, 10(2), 7-13. Available at www.ijbel.com

Mulindabigwi, R. C., \& Kayitana, C. (2018). Mind-Set and Entrepreneurial Activities in Rwanda: A Firm Level Investigation. East Africa Research Papers in Business, Entrepreneurship and Management. Available at: https://includeplatform.net

Muhammad, G. U., \& Aina, A. N. (2017). Entrepreneurial Competencies: SMEs Performance Factor in the Challenging Nigerian Economy. Academic Journal of Economic Studies 3(4). Retrieved from https://ideas.repec.org 
Mukiri, K. B., Mukulu, E., \& Odhiambo, R. (2019). Effect of Innovation on The Performance of Small and Medium Enterprises. International Journal of Entrepreneurship, 2(1). 1528. Retrieved from www.ajpojournals.org

Nasir, J.T.N., \& Chellakan, R. S. (2020). Effect of Entrepreneurial Competence and Expansion Strategies on SMES Performance of Kingdom of Bahrain. iKSP Journal of Business and Economics, 1(1) 1-13. Retrieved from http://iksp.org/journals/index.php/ijbe/index

Neneh, N. B. (2012). An exploratory study on entrepreneurial mindset in the small and medium enterprise (SME) sector. A South African perspective on fostering small and medium enterprise (SME) success. African Journal of Business Management, 6(9).

Odunayo, T. (2015). Entrepreneurial Orientation: A Remedy for Receding Productivity of Small and Medium Scale Enterprise: A Nigeria Perspective. Entrepreneurship \& Economics eJournal. http://dx.doi.org/10.2139/ssrn.2555436

Ofosuaa, O., Duku, M., Boadi, B. R., \& Dorgbley, K. P. (2015). Role of Small and Medium scale Enterprises in The Economic Development of Ghana (Thesis undergraduate), Kwame Nkrumah University of Science and Technology Kumasi. Retrieved from https://www.academia.edu

Onwuchekwa, F., Ejike, D., \& Mgbemena, G. (2017). The Role Of Entrepreneurial Competencies In Promoting Entrepreneurship In Nigeria: A Study Of Practicing Entrepreneurs In Anambra State, Nigeria. An International Multi Disciplinary Journal, Ethiopia, 11(2). Available at: https://www.ajol.info

Organization for Economic Cooperation and Development. (2018). Developing entrepreneurship competency Ministerial Conference on Small and Medium-sized Enterprises.

Oyeku, O., Oduyoye, O. (2014). Entrepreneurial Capability And Entrepreneurial Success Of Small And Medium Enterprises: A Review Of Conceptual And Theoretical Framework. Research on Humanities and Social Sciences, 4(17), Available at: https://www.iiste.org/

Robles, L., \& Zárraga-Rodríguez, M. (2015). Key Competencies for Entrepreneurship. Procedia Economics and Finance, 23, 828-832. Available at: https://core.ac.uk/

Sanchez, J. (2012). The influence of entrepreneurial competencies on small firm performance. Revista Latinoamericana de Psicología, 44(2). Available at: http://www.scielo.org

Srinivasa, R. (2000). Lecture note on entrepreneurial development for MBA Institute of Aeronautical Engineering. Available at http://www.crectirupati.com

Suvittawat, A. (2019). Entrepreneurial Passion Domains of Small and Medium Enterprises(SMES): A case study of Lower North Eastern, Thailand. International Journal of Entrepreneurship, 23(1).

Tehseen, S., \& Ramayah, T. (2015). Entrepreneurial Competencies and SMEs Business Success: The Contingent Role of External Integration. Mediterranean Journal of Social Sciences, 6(1), 50-61. Available at: https://www.mcser.org

Ummah, S. (2019). Impact of Entrepreneurs' Behaviour on Growth of Small and Medium Enterprises (SMEs): Special Reference to Udunuwara Division. Journal of Management 14(2), 51-58. Retrieved from http://www.orcid.org

University of Melbourne. (2020). An introduction to systematic reviews, with examples from health sciences and medicine. Available at https://unimelb.libguides.com 
Victor, X. W. (2018). Critical Theory And Transformative Learning. Google Books. Available at: https://books.google.com.et/books

Vijay, \& Ajay, V. (2011). Entrepreneurial Competency in SME'S. Bonfring International Journal of Industrial Engineering and Management Science, 1(1), 05-10. Available at: https://citeseerx.ist.psu.edu

Vignesh, S., \& Vetrivel, (2017). A Study on Entrepreneurial Competencies among the MBA Students of Chennai with Special Reference To Initiative, Problem Solving and Information Seeking Competencies. Journal of Business and Management (IOSR-JBM) 19(8), 29-32. Available at http://www.iosrjournals.org

Wanguinjeru, P. (2012). The Effect of Entrepreneurial mindset on the performance of manufacturing business in Nairobi industrial area (PhD Dissertation).

Zahan, L. N., \& Kanit, B. T. (2014). Relationship between Entrepreneurial Competencies of SME Owners/Managers and Firm Performance: A Study on Manufacturing SMEs. Journal of Entrepreneurship And Management 3(3). Available at http://www.publishingindia.com

Zizile, T. (2018). The Importance Of Entrepreneurial Competencies on The Performance Of Women Entrepreneurs In South Africa. The Journal of Applied Business Research, 34 (2). Available at www.clutejournals.com

$\mathrm{Xu}, \mathrm{X}$. (2020). Introduction to Entrepreneurship Methodologies and practices. Springer texts in Education. https://doi.org/10.1007/978-981-15-1839 